San Jose State University

SJSU ScholarWorks

Faculty Publications

School of Global Innovation and Leadership

2-3-2021

\title{
Taking advantage of institutional weakness? Political stability and foreign subsidiary survival in primary industries
}

\author{
Nathaniel C. Lupton \\ San Jose State University, nathaniel.lupton@sjsu.edu \\ Donya Behnam \\ University of Lethbridge \\ Alfredo Jiménez \\ Kedge Business School
}

Follow this and additional works at: https://scholarworks.sjsu.edu/sgil_pub

Part of the International Business Commons, and the Technology and Innovation Commons

\section{Recommended Citation}

Nathaniel C. Lupton, Donya Behnam, and Alfredo Jiménez. "Taking advantage of institutional weakness? Political stability and foreign subsidiary survival in primary industries" Multinational Business Review (2021). https://doi.org/10.1108/MBR-02-2020-0043

This Article is brought to you for free and open access by the School of Global Innovation and Leadership at SJSU ScholarWorks. It has been accepted for inclusion in Faculty Publications by an authorized administrator of SJSU ScholarWorks. For more information, please contact scholarworks@sjsu.edu. 


\section{Taking Advantage of Institutional Weakness? Political Stability and Foreign Subsidiary Survival in Primary Industries}

\begin{tabular}{|r|l|}
\hline Journal: & Multinational Business Review \\
\hline Manuscript ID & MBR-02-2020-0043.R4 \\
\hline Manuscript Type: & Research Paper \\
\hline Keywords: & $\begin{array}{l}\text { Foreign Direct Investment (FDI), anti-globalization, legal compliance, } \\
\text { natural resources, primary industries, subsidiary exit hazard }\end{array}$ \\
\hline \multicolumn{2}{|l}{} \\
\hline
\end{tabular}

\section{SCHOLARONE ${ }^{m}$ \\ Manuscripts}




\title{
Taking Advantage of Institutional Weakness? Political Stability and Foreign Subsidiary Survival in Primary Industries
}

\begin{abstract}
Purpose: We investigate the extent to which locating primary industry subsidiaries in politically unstable countries impacts their survival. We argue that foreign multinational enterprises in less stable political environments can shape policies that are impactful on the costs of operating in primary industries and avoid compliance with more stringent policies at home.

Methodology: Using a sample of 753 primary sector investments of Japanese multinational enterprises during the period 1986 to 2013, we conduct a parametric survival analysis of the relationship between political stability and subsidiary survival.

Findings: Political instability has a slight, curvilinear relationship with subsidiary survival, such that both high and low stability are associated with lower exit hazard, while moderate levels of stability increased exit hazard. This nonlinear relationship is stronger for efficiency-seeking subsidiaries, and weaker for market-seeking subsidiaries.

Originality: This research contributes to the debate around the pros and cons of globalization by examining the extent to which firms benefit by offshoring primary sector investments to avoid more costly legal requirements at home. The results suggest that this non-market strategy should be mitigated through appropriate policy measures and provides evidence that those policies already implemented are effective.
\end{abstract}

Keywords: Foreign Direct Investment (FDI), anti-globalization, legal compliance, natural resources, primary industries, subsidiary exit hazard 


\section{Introduction}

Economic globalization, the process by which economic activity increases and becomes more integrated across national borders, has accelerated in recent decades, as foreign direct investment (FDI) expands the global reach of production, international trade, consumption, knowledge, and technology (Guillén, 2001). While there are many positive outcomes associated with globalization, such as increasing pressures on governments to adopt pro-market reforms, improve living standards, and support basic human rights, which together have contributed to a substantial reduction in the rate of global poverty, globalization clearly has its detractors (Bhagwati, 2002, 2004; Cuervo-Cazurra et al., 2019; Meyer, 2017).

While not exclusive to market-oriented economies, anti-globalization sentiment has its highest impact there, with opposition voiced towards the offshoring of production and service jobs, accelerating environmental degradation, and promoting low-standard working conditions. Likewise, increased returns to capital and reduced expenditure on social benefits within the communities in which multinational enterprises (MNEs) operate, uneven distribution of the benefits of globalization, and the elimination of the middle class, are all seen as the drivers of rising economic inequality in the developed countries (Alvaredo et al., 2013; Piketty, 2014). In this paper, we seek to understand the extent to which locating MNEs in politically unstable countries impacts their performance, in order to provide empirical evidence about the non-market activities of MNEs, as shapers, and avoiders, of legal requirements.

Whereas most studies concerning FDI and political stability are concerned with the impact of host country characteristics on the location and entry mode of MNEs' FDI, our study examines the role of political stability, amongst other location characteristics, on the survival of primary sector (i.e. natural resources) subsidiaries. We conduct our research in the primary industries 
because this sector tends to be capital intensive, leading to higher sunk costs of investment in relatively immobile assets, and hence high sensitivity to incremental cost implications of legal requirements. Hence both location and relocation decisions require substantial due diligence. Furthermore, these industries conduct activities which are subject to a host of regulations aimed at environmental protection, worker safety, and employment standards. We choose subsidiary survival (inversely operationalized as exit hazard) as our performance indicator, as profitability and market measures of performance tend to be more appropriate when evaluating the overall performance of MNEs, rather than individual subsidiaries (Ariño, 2003).

We argue that MNEs face a tradeoff between higher transaction- and compliance-costs, depending on the degree of political stability in potential host countries. As a result, we argue that subsidiaries experience the highest survival rates (i.e. lowest exit hazard) when they are established in either the most (lowest transaction costs) or least (lowest compliance costs) politically stable countries. Consequently, as political stability increases, hazard rates first increase and later diminish, resulting in an inverted U-shaped relationship between political stability and exit hazard. To further test the posited tradeoff between transaction and compliance costs, we also examine how the relationship varies depending on investment motives. Prior research in the field has employed several theoretical perspectives such as transaction cost economics, population ecology, institutional theories, etc. to explain the determinants of MNE subsidiaries' survival (Demirbag et al., 2011). Yet, the role of compliance costs in 'escape' FDI has not been fully assessed (Barnard and Luiz, 2018; Cuervo-Cazurra, 2016).

Combining the logic of FDI and institutional economic theories (Cantwell et al., 2010; Dunning and Lundan, 2008), we argue that political instability can allow firms greater leeway in influencing domestic policy and providing protection from unfavorable policy decisions. When 
political stability is high, firms enter a host country with a better understanding of the 'rules of the game' (North, 1987). Highly stable environments reduce the risk of obsolescing bargains and other expropriation risks (Henisz, 2000; Kobrin, 1979), while protecting firms' assets and intellectual property rights that underpin their firm-specific advantages (Weingast, 1993). Hence political stability is expected to reduce transaction costs, thereby improving the performance, and ultimately survival, of foreign subsidiaries.

However, we argue that while MNEs may face lower transaction costs, they may experience higher compliance costs when located in countries with high political stability (CuervoCazurra, 2016; Witt and Lewin, 2007), especially in the primary sector, in which a diverse set of stakeholders promote competing priorities (Kobrin, 1979). In the case of labor market regulations and workplace safety, for example, increased costs tend to reduce location attractiveness (Cheng, 2006; Cooke, 1997). Similarly, more stringent financial reporting requirements, environmental protection regulations, and working conditions can reduce the ability of a subsidiary to adapt to changing global demand and regulations, thereby inducing closure or relocation of operations (Barnard and Luiz, 2018). Hence, firms face a trade-off between transaction and compliance costs when considering the political instability of a location.

We employ mixed-effects parametric survival analysis to test our predictions on a nearpopulation level sample of Japanese overseas direct investments in primary industries operating during the period 1986-2013. We find evidence to support the predicted inverted U-shaped relationship between political stability and subsidiary exit hazard, although the relationship was predominantly positive, with a much smaller diminishing effect at high levels of instability. The strength of this relationship was impacted by efficiency- and market-seeking motives but not by natural resource-seeking and asset-seeking motives. 
This research contributes to the debate on the merits of globalization (Lewin and Peeters, 2006; Meyer, 2017), specifically through examining the extent to which MNEs may use weak regulatory regimes to exploit workers and avoid environmental protection and financial reporting transparency. While we find some support that subsidiaries face reduced exit hazard at opposite extremes of political stability, rather than in more moderate stable political environments, the extent to which this is occurring should not be exaggerated. Specifically, the use of institutional arbitrage by Japanese MNEs to seek an advantage over domestic firms, while undermining efforts to improve environmental and social performance, appears rare. Our findings support the call to extend FDI theory through examining the impact of internalizing non-market failures (Buckley, 2018), such as political instability, and contributes to outlining the boundary conditions on FDI theory by taking into consideration the sometimes neglected characteristics of the primary industries, especially the substantial impact of non-market transactions on performance.

\section{Theory and Hypotheses}

\subsection{Political stability and subsidiary survival in the primary sector}

Early arguments in favor of international trade and economic globalization are rooted in the Heckscher-Ohlin factor endowment theory, in which differences in land, labor, capital, and technology guide specialization within, and trade between, countries (Schott, 2003). Institutional economists and business scholars later added the role of MNEs as transaction cost minimizers, overcoming deficiencies in the institutional systems that support an efficient market, with a strong emphasis on the negotiation and enforcement of incomplete contracts (Dunning, 1977; Hennart and Park, 1994). Political stability, which reflects the reliability of the institutions governing 
contracts and property rights (Jensen, 2006; Slangen and Van Tulder, 2009), is widely studied as FDI location characteristic that impacts both ex-ante and ex-post transaction costs. Heightened political risk creates an unpredictable business environment characterized by large and abrupt changes in taxation, contract law, policies on expropriation, and other legal mechanisms, which in turn leads to higher contracting costs (i.e. negotiation, monitoring, and enforcement costs) (Crowley and Loviscek, 2002; Darendeli et al., 2020). International business scholars have relied on transaction cost arguments for location choice and entry mode studies, generally finding that lower transaction costs are favored and that higher ownership by the MNE is the preferred method for reducing transaction costs (Delios and Beamish, 2001; Demirbag et al., 2011).

Although politically stable environments allow for more efficient transactions, research has not always found a positive relationship between political stability and location choice or performance of international investments (Barassi and Zhou, 2012; Helmy, 2013). When government policy is more volatile, negotiation can be a more effective tool for foreign firms to shape policy, and building informal networks with government actors will help MNEs to create competitive advantages (White et al., 2014). Enhanced negotiation and lobbying skills, which accrue to firms as a consequence of working in a politically unstable environment, can be a source of advantage for firms (García-Canal and Guillén, 2008; Yasuda and Mitsuhashi, 2017). Lobbying capabilities can enhance firms' influence over the government and adapt to environmental changes (Lawton and Rajwani, 2011; Lawton et al., 2013). In extreme cases, politically unstable environments may even allow firms to violate environmental protection laws without being held accountable. These benefits, however, are offset by the foreseeable catastrophic events arising from lax oversight, for example, the armed attacks and a mine collapse which have killed many Freeport McMoRan's employees in its Grasberg mine operations in Indonesia. 
Anti-globalization arguments rarely focus on transaction cost minimization. Instead they criticize cost reduction through offshoring and/or outsourcing jobs, evading regulatory requirements related to minimum wages, working conditions and employee benefits, environmental protection and stewardship, taxation, and financial reporting. These actions are perceived to undermine the functioning of civil society and the sovereignty of the state (Bhagwati, 2004). We refer to these as institutional arbitrage arguments against globalization.

Institutional arbitrage is a non-market strategy by which firms locate specific functions in countries that have the most favorable legal environment for that function, in terms of production and/or transaction costs (Jackson and Deeg, 2008; Witt and Lewin, 2007). Typically, firms that engage in institutional arbitrage tend to offshore activities when the institutional environment of their home country is weak (Rosenbusch et al., 2019). However, this strategy can also be used to escape home countries with strong institutions that are strong, in terms of compliance costs and enforcement, such as in the case of more stringent pollution control (Li and Zhou, 2017). Antiglobalization arguments related to institutional arbitrage generally revolve around the idea that differences in policies, policy enforcement, and human rights allow MNEs to pit countries against one another to attract FDI, in a competition to provide the lowest possible standards (Davies and Vadlamannati, 2013), which result in the lowest compliance costs related to environmental protection, improved working condition, financial reporting standards, etc. Firms may invest in pollution havens, i.e., countries where environmental regulations are less restrictive (Dasgupta et al., 1999), especially those in "dirty" industries (Copeland and Taylor, 1994). Previous studies show that a reduction in regulatory stringency leads to increasing FDI inflows (Tang, 2015; Wagner and Timmins, 2009). In the case of primary industries, work is typically either technology or labor-intensive, and so MNEs can benefit by locating in countries with lower labor standards 
to avoid costly technological upgrading (Weng and Peng, 2018). Finally, the International Financial Reporting Standards (IFRS) refer to a set of rules that financial statements around the world follow to increase transparency and comparability across countries (Akpomi and Nnadi, 2017; Nnadi and Soobaroyen, 2015). The impact of IFRS on attracting FDI in previous studies shows a mixed effect. Some argue that more transparency leads to increasing FDI (Gordon et al., 2012; Márquez-Ramos, 2011), whereas Nnadi and Soobaroyen (2015) argue that it leads to lower FDI as a result of the increasing the cost of financial reporting.

Examples of compliance costs in the primary sector include the incrementally higher cost of using environmentally friendly construction techniques for facilities, extraction and production processes, maintaining improved working conditions, and paying higher wages (Surroca et al., 2013). Hence, MNEs are generally faced with tradeoffs between at least two types of incremental costs when choosing between domestic and foreign locations for investment; namely transaction costs and compliance costs. Countries with high political stability tend to be more democratic, and possess more stable, liberalized economies, achieved through the creation of effective institutions to protect contracts and property rights, thereby reducing transaction costs (Holburn and Zelner, 2010). However, partly as a result of being more democratic, the law serves a greater variety of stakeholder interests, which results in higher compliance costs (Barnard and Luiz, 2018).

In summary, a highly stable political environment provides contractual provisions that are reliable, thus shielding foreign firms' investments in the primary sector from increased transaction costs and improving their survival. However, the opportunity for negotiating policies and reducing compliance costs creates more flexibility for firms to shape the policy environment based on their interests which, in the extreme, can involve bribery and corruption (Jiménez and Alon, 2018; Park, 2003; Yim et al., 2017). In situations where corruption is prevalent, regulation and agreements can 
have different impacts as a result of varying interpretations and the arbitrary enforcement of laws. Proactively engaging with a politically unstable system helps the MNE to bargain with government and political institutions to shape policies in their favor while benefitting from lower compliance costs (Bertrand et al., 2019; Rodriguez et al., 2005; Uhlenbruck et al., 2006; Yi et al., 2019). Firms that are more adept at lobbying and negotiation with government and legal actors can take advantage of lower compliance costs in politically unstable countries, while being less affected by increased bargaining costs, as compared to less-experienced competitors, in executing non-market strategies (Darendeli and Hill, 2016; Pinkse and Kolk, 2012). As a result, we predict that both low and high levels of political stability result in a highest primary-sector firm survival rate.

Hypothesis 1: The relationship between political stability and subsidiary exit hazard in the primary sector is inverted U-shaped: The lowest and highest levels of political stability are associated with lower exit hazard, while moderate levels of stability are associated with higher exit hazard.

\subsection{Moderating effect of FDI motives in the primary sector}

The effect of location characteristics on subsidiary performance depends on the MNE's motive for investing (Benito, 2015). Resource-seeking, efficiency-seeking, market-seeking, and strategic asset-seeking are the four conventionally defined FDI motives. Natural resource-seeking refers to accessing natural resources that are abundant in the target country. Efficiency-seeking involves leveraging factor cost differences in the host country, market-seeking addresses 
opportunities for foreign countries to exploit economies of scale or to extend product lifecycles, and, strategic assets-seeking looks to create long-term advantages by transferring knowledge to and from the host country (Meyer, 2015).

For firms that have natural resources and market-seeking motives the cost of compliance with environmental standards, such as emission monitoring, impact monitoring, and technological upgrading, is high (Tang, 2015). Moreover, firms in countries with higher labor standards pay a premium for costs of hiring, labor benefits, and physical safety procedures (Friedman, 2000). Since both firms with natural resource-seeking motives and efficiency-seeking motives are looking for labor at lower prices, countries with lower labor costs would provide a more efficient place to operate. Finally, the cost of IFRS is higher for firms with market-seeking motives. Corruption and bribery are common in the natural resource sector, and a less transparent IFRS can help conceal these costs (Mckinney and Moore, 2008). A summary of the compliance costs on investment motives are shown in Table 1.

Insert Table 1 about here

In natural resource industries, resource-seeking is the assumed overarching investment motive (Jones, 2005). Cheaper or more accessible resources are the main factors impacting foreign country location choice. Most countries rich in natural resources are closely tied to the global 
economy and seek FDI to build the capacity of their extractive industries. Low stability (high instability) introduces added contracting costs, incurred to reduce policy uncertainty. However, low stability can also benefit the firm by allowing it to participate in shaping emergent policy regimes. Favorable awarding of contracts, concessions, and cooperation to achieve illegal goals are examples of the mechanisms that ease access to resources (Hall, 1999; Kolstad and Wiig, 2013).

Whereas in stable policy environments institutions it may not be as easy for MNEs to shape emergent policies as it is in unstable countries, they can still increase the operational efficiency by forming close relationships with powerful stakeholders, with whom they can align to achieve mutual goals. Overall, this leads to a less complex and hence less costly set of bargaining constraints. We therefore argue that investments in the primary sector with a natural resourceseeking motive will exhibit a steeper curvilinear relationship between political stability and subsidiary survival:

Hypothesis 2a: The inverse U-shaped relationship between political stability and subsidiary exit hazard in the primary sector will be steeper when a firm has a natural resource-seeking motive.

For firms with efficiency-seeking motives, cost economization is the primary objective (Dunning, 2000). In extraction industries, transportation and distribution costs are some of the most important considerations for an MNE, along with the cost of labor, and complying with 
product and environmental regulations (Li and Zhou, 2017; Weng and Peng, 2018). To overcome these costs, firms can take part in the process of establishing regulations, and even in the development of the infrastructure necessary to improve access to natural resources. Illegal payments methods, such as paying bribes to win contracts or to access raw materials with government subsidies, or paying lower interest rates, can all increase the financial efficiency of the investment (Hall, 1999; Surroca et al., 2013).

While higher political instability provides an opportunity for firms to gain more efficient access to commodities, increased scrutiny by home country regulators (e.g. Securities and Exchange Commission in the US, Securities Exchange Surveillance Commission in Japan) and international watchdogs (e.g. Transparency International, Greenpeace) can make it increasingly risky to take advantage of weak institutions. Section 1502 of the Dodd-Frank Act, for example, was specifically designed to mitigate the impact of MNEs' sourcing of commodities including tin, tungsten, tantalum, and gold, from fragile states, especially Congo and its surrounding neighbors. The Act requires US firms (and those listed in the US) to disclose procurement of commodities from these countries, and their efforts to curtail funding of armed militias or human rights abusers. The goal of this initiative has been replicated by countries around the world including those in the EU and Japan. Since MNEs' operations within these countries are subject to even greater scrutiny, we expect that the survival of subsidiaries in such highly unstable environments would be subject to increased risk.

In summary, natural resource firms can use increasing political instability as a tool to gain efficient access to commodities, but relatively recent attention to those areas that are most unstable (the fragile states) has increased the risk of doing so. We therefore expect a stronger curvilinear 
7

8

9

relationship between political stability and subsidiary survival in the primary sector, so we argue that:

Hypothesis 2b: The inverse U-shaped relationship between political stability and subsidiary exit hazard in the primary sector will be steeper when a firm has an efficiencyseeking motive.

Market size and the degree of a market's development are the top priorities of marketseeking investments, while labor and transportation costs are secondary (Makino et al., 2002).. As highly traded commodities, the prices for natural resources tend to closely follow world prices. Nonetheless, these commodity prices are not necessarily indicative of what end consumers or production industries pay. In many countries and industries, prices paid for commodities by consumers and intermediaries in protected industries are subsidized (Mcmullen and Bergman, 2018). Conversely, in other countries, commodity taxes are a key source of government revenue (Vetter, 2017). While political stability will create volatility in both subsidies and taxes, only a small proportion of firms are better able to capitalize on instability (Holburn and Zelner, 2010). Commodity giant BHP Billiton, for example, was charged under the Foreign Corrupt Practices Act (FCPA) for hosting government officials at the 2008 Beijing Summer Olympics, an act judged to be undertaken to gain more favoritism when awarding contracts.

Although a small number of market-seeking MNEs will benefit from volatile commodity pricing, taxation, and subsidies, the vast majority are negatively impacted. Additionally, less stable 
policy environments lead to lower economic growth, which in turn limits demand for natural resources in general (Brouthers et al., 2008; Henisz, 2000; Keefer and Knack, 2002). Investments made with a market-seeking motive in the primary sector will, therefore, experience a weaker positive relationship, potentially even becoming negative, between low to moderate stability and exit hazard, and a stronger negative relationship from moderate to high political stability. We therefore predict:

Hypothesis 2c: The inverse U-shape relationship between political stability and subsidiary exit hazard in the primary sector will be flatter when a company has a market-seeking motive.

Knowledge assets and human resource stocks are typically among the most important strategic assets sought by MNEs. As pressures to address carbon and other undesirable emissions from natural resource extraction increase, firms have responded by making costly capital investments in clean technology. Subsidiaries located in less politically stable countries are better able to lobby against increasing environmental protection policies, thus avoiding these additional expenses (Weng and Peng, 2018). It is therefore unlikely that these subsidiaries will be harvested as MNEs adjust their global investments in the face of environmental protection policies. However, firms with strategic asset-seeking motives are unlikely to reduce their investment in enhanced environmental protection policies. These MNEs seek to improve their knowledge and competencies through accessing an educated and skilled workforce, operating in a knowledgesharing environment characterized by trustworthiness (Li et al., 2012). As lower political stability tends to lead to an environment in which governments provide fewer educational resources to a 
more limited number of people, the pool of educated and highly skilled employees is reduced (Barnard, 2008). This limited pool of knowledgeable employees rises demand, thus increasing their cost to the firm. This helps explain why firms from countries with greater technological development capabilities tend to dominate these industries, as they can extract resources more efficiently. Thus, if a firm in the primary sector has a strategic asset-seeking motive, particularly in the natural resources industry, highly unstable political environments are not conducive to achieving that motive (Barnard, 2008; Sarfati, 2015). Therefore, we predict that:

Hypothesis 2d: The inverse U-shaped relationship between political stability and subsidiary exit hazard in the primary sector will be flatter when a company has an assetseeking motive.

\section{Methodology \\ 3.1. Data source}

We use data on foreign subsidiaries from Toyo Keizai's overseas investment (TK) dataset to test the hypotheses. This dataset, updated annually, provides information about Japanese firms' investment in foreign countries. Data are gathered through interviews with general managers, who provide information on each subsidiary of their parent company, including duration of the activity, start date, exit date, type of industry, parent firms, the purpose of investment, and so forth. The sample for this study consists of 6,082 observations and includes all Japanese firms that invested 
in the primary sector industries, in 65 foreign countries, from 1986 to 2013. After dropping observations with missing data, the final number of observations is 5,726 subsidiary-years.

\subsection{Dependent variable}

The dependent variable for this study is subsidiary survival, which is operationalized as the conditional probability of exit/closure during the time of study of Japanese subsidiaries in the natural resources sector. This measure is a binary variable, coded as one when a subsidiary disappears from the panel prior to 2013 (i.e. exited). Those subsidiaries that survived to the 2013 edition of the dataset are considered as censored data (time to exit unknown) and hence are coded as zero.

\subsection{Independent variable}

The main independent variable in this study is political stability, drawn from The PRS Group database. We rely on a comprehensive operationalization of political stability, consisting of factors related to both political risk and uncertainty (Slangen and Van Tulder, 2009). The PRS Group dataset provides this information based on two methodologies. The first is based on the rate of change of policies, the general political environment, and tariff procedures. The second measures political events and considers how these events impact factors such as gross domestic product (GDP), inflation, and exchange rate stability. The combination of these two methodologies results in an overall metric for countries' risk which is highly relevant to FDI decisions. The content domain was selected by The PRS Group specifically to address the concerns of foreign direct investors. 


\subsection{Moderators}

The motives behind investing in host countries were obtained from the TK dataset. The dataset is compiled from an annual survey that is completed by senior managers, who select from a list of predefined investment purposes for each subsidiary of their MNE. We further categorize these purposes according to prior literature on the four motives (Chrysostome and Lupton, 2011). Table 1 depicts the encoding of these objectives into the four 'seeking' categories.

\subsection{Control variables}

We include several control variables based on prior studies of FDI performance and survival. GDP growth and GDP per capita proxy the rate of changes and living standards of each country, respectively, while GDP per capita also proxies labor costs (Mayer et al., 2010). Population is included as a proxy for labor supply (Mayer et al., 2010). The openness to trade index, which reflects the degree of importing and exporting activities undertaken by domestic firms and investors, is measured by the trade ratio, drawn from the World Trade Organization (Delios and Beamish, 2001; Meschi et al., 2016). To control for overall FDI attractiveness of each country for investors, we use net FDI inflows (Brouthers et al., 2008).

\subsection{Analytical approach}

We use a mixed-effects parametric survival model to predict the probability of occurrence of a time-dependent event (subsidiary exit), based on a set of predictors (Austin, 2017) and dependent upon a set of moderators (purposes of investment). The event modeled was time to subsidiaries' exit over a period of 26 years, from 1986 to 2013, with left censoring. The main assumption in the parametric survival model is the shape of the hazard baseline function. The term 'mixed-effects' is refers to models that include both random and fixed effects (Crowther et al., 
2014). To analyze multiple random effects in a specific cluster, the mixed effects parametric survival analysis model is used. This model is formulated as shown in equation 1 , in which $u_{j}$ represents the cluster $\mathrm{j}$ (cluster refers to a group of individuals that share the same characteristics) and $z_{j i}$ represents the covariates that are related to the random effect and $\boldsymbol{v}_{i j}$ represents the observation-level error (Austin, 2017). The Weibull distribution exhibited the best fit for our data, according to AIC (Akaike Information Criterion), so this distribution was used to model the baseline function. Equation 2 formalizes the baseline hazard function (Cleves et al., 2010).

Equation 1: Multilevel Mixed Effects Parametric Survival Model:

$$
h\left(t_{i j}\right)=h_{0}\left(t_{i j}\right) \exp \left(x_{i j} \beta+z_{j i} u_{j}+v_{i j}\right)
$$

Equation 2: Weibull Distribution Baseline Hazard:

$$
h_{0}(t)=p t^{p-1} \exp (\alpha)
$$

To estimate the baseline hazard, this model was fit to the parameters $\left(\alpha, \mathrm{p}, \beta_{i}\right)$, that is the hazard ratio of the coefficients of the $\mathrm{i}^{\text {th }}$ covariate, with the shape of the baseline represented by $p$ as one parameter and $\alpha$ as the second parameter to estimate the baseline hazard (Cleves et al., 2010). We selected a mixed-effects model because moderators that are reported in the TK dataset are subsidiary-level variables, while the independent variable (political stability) and control variables are country-level. To account for the differing levels of analysis, and the unobserved heterogeneity among subsidiaries, the survival model included subsidiary-level fixed effects, 
based on the subsidiary ID code. We estimated our model using the mestreg procedure in STATA 15.

\section{Results}

Table 2 shows the summary of sample statistics and the correlation between variables. To check the proportionality assumption, we employ the Schoenfeld residuals test. Since the null hypothesis of the Schoenfeld residuals test is that the hazard rate is constant over time, the nonsignificant test $(p=0.27)$ indicates that the null hypothesis cannot be rejected, and thus the proportionality assumption is supported.

Insert Table 2 about here

Table 3 reports the results of running mixed effect parametric models. Model 1 includes the control variables. We added the linear term and the quadratic term of country risk in Model 2 and Model 3, respectively. Models 4 to 7 include interaction terms. The Wald test chi-squared represents how the fit of models changes with adding different covariates. The null hypothesis of the Wald test is that adding a variable to the model does not add any value and removing a variable from the model does not impact the fit. As shown in Table 4, the chi-squared statistics of each model are significant, which means the Wald test is different than zero, and adding additional variables to the model significantly improved the overall fit. The log-likelihood function performs a similar function to the Wald test, i.e. it allows one to assess model fit, but is different from the Wald test in that log likelihood requires two models for comparison. To interpret the coefficients 
properly we standardized and mean-centered the country risk. Country risk coefficients show that one standard deviation difference in country risk is associated with a significant change in hazard of exit.

Insert Table 3 about here

Hypothesis 1 predicted a curvilinear relationship between political stability and subsidiary survival. To test Hypothesis 1, Model 2 and Model 3 in Table 3 are used. Model 2 contains the linear term of country risk (as a measure of political stability) and control variables. As the coefficient represents the hazard rate, the significant $(p<0.001)$ and positive sign of the coefficient shows that one standard deviation difference in country risk is associated with a $3.6 \%$ increase in the standard deviation of the hazard of exit. Since Hypothesis 1 proposed that political stability has a curvilinear relationship with subsidiary survival, the squared term of country risk was added in Model 3. This significant model $(\mathrm{P}<0.001)$ suggests that the effect of country risk on subsidiary survival is not a linear relationship. Adding the quadratic term (country risk squared) to the model represented the curvilinear effect of country risk on the exit rate, which changes when subsidiaries experience a higher level of risk. The negative coefficient of the quadratic term estimates an increase and then a decrease in the exit-hazard rate (inverted-U).

As shown in Figure 1, the highest failure rate occurs when host country risk is up to one standard deviation higher or one standard deviation lower than the mean, and the subsidiaries which face the lowest degree of risk are in countries with the highest degree of political risk (more than one standard deviation above the mean). Hence, the lowest and the highest degree of political 
risk are associated with the lower exit hazard and a moderate degree of political risk is associated with a higher exit hazard.

Hypothesis 2 a concerned the moderating effect of natural resource-seeking motive on the relationship between political stability and subsidiary survival. The interaction terms between country risk and natural resource-seeking were added to Model 5 to test Hypothesis 3a. The pvalues of country risk $x$ natural resource-seeking and squared country risk $x$ natural resourceseeking ( $p=0.32$ and $p=0.253$, respectively) do not provide evidence that natural resourceseeking has a moderating effect on the relationship between political stability and subsidiary survival. Therefore, Hypothesis 3a is not supported.

Hypothesis $2 \mathrm{~b}$ concerned the moderating effect of efficiency-seeking motive on the relationship between political stability and subsidiary survival. The coefficients for the interaction terms country risk $x$ efficiency-seeking and country risk ${ }^{2}$ x efficiency-seeking in Model 6 are marginally significant $(\mathrm{p}=0.051$ and $\mathrm{p}=0.056$, respectively). This offers marginal support for Hypothesis $2 b$, that efficiency-seeking motives improve subsidiary survival in politically unstable countries. This marginally supports the argument that efficiency-seeking motives reduce a subsidiary's hazard of exit when political instability increases, although the effect is relatively small in this case.

Hypothesis 2c concerned the moderating effect of market-seeking motives on the relationship between political stability and subsidiary survival. Model 7 includes the interaction terms between country risk and political stability. The $\mathrm{p}$-values of country risk $\mathrm{x}$ market-seeking and country risk ${ }^{2} \times$ market-seeking are marginally significant $(\mathrm{p}=0.072$ and $\mathrm{p}=0.108$, respectively). This significant interaction supports Hypothesis 2c which predicts that having 
market-seeking motives reduces subsidiary survival when the level of political instability increases. As the coefficient of country risk increases by about $10 \%$, this means that having this investment motive increases the chance of exit, and an additional increase in the country risk leads to a $0.1 \%$ increase in the exit hazard compared to Model 3, where no interaction term was added.

Hypothesis $2 \mathrm{~d}$ concerned the potential moderating effect of strategic asset-seeking motive on the relationship between political stability and subsidiary survival. To test this hypothesis, the interaction terms country risk $x$ strategic asset-seeking and country risk ${ }^{2}$ x strategic asset-seeking were added in Model 8. The $p$-value of these interactions is not significant $(p=0.728, p=0.737)$; therefore, Hypothesis $3 \mathrm{~d}$ is not supported.

Insert Figure 1 about here

\section{Discussion}

Our paper contributes to the special issue call by finding empirical evidence that MNEs in the primary sector benefit by exploiting low policy compliance costs in politically unstable countries, which is a common criticism of globalization (Bhagwati, 2002, 2004; Guillén, 2001). We provide evidence that the benefits of engaging in this sort of institutional arbitrage can contribute to a lower subsidiary exit hazard in politically unstable countries. However, the effect is small compared to the positive relationship between political instability and exit hazard. While few would agree that exploitation of unstable countries by MNEs is much ado about nothing, and 
one can readily find unsettling examples, lack of transparency and difficulty in detecting unethical behavior creates challenges for policymakers interested in eliminating this behavior. For instance, in the previously mentioned case of the Freeport McMoRan's mine in Indonesia, the close links with the Suharto regime and the military have protected the company from accusations of environmental damage, oppression of native West Papuan people, and even allegedly collaboration with Indonesian military intelligence officers to monitor environmentalists' e-mails and telephone conversations. To apply the logic of one of the original institutional economists, there is a significant cost to policing foreign activities of firms (Coase, 1937). This is perhaps not surprising, as it takes significant time for lobbying efforts to impact MNEs, as in the oft-cited case of Nike, and that natural resource companies are neither readily recognized nor boycotted by consumers.

We chose to study extractive industries because there are significant opportunities for firms to exploit institutional differences in this sector (Casarin et al., 2020), including locating in pollution havens, and likewise that the large capital investments would benefit greatly from cost reduction through using older technologies, 'dirtier' extraction techniques and reduced investment in workplace safety. In the manufacturing and service sectors, instability is found to curtail investments (Barry, 2016; Delios and Henisz, 2003). We have argued that the relationship between political stability and subsidiary survival is curvilinear in the extractive industries because resources are what initially bring a location under consideration, while the host country stakeholders are more or less willing to negotiate on rents, tax, labor conditions, and so forth (Schultz, 2009). Some analysts have estimated that the oil and gas sector, in particular, spends as much as USD 200 million, lobbying to influence policy aimed at mitigating climate change (Mccarthy, 2019). 
We contribute also to the subsidiary survival literature by providing evidence on how subsidiaries in the primary sector react to different levels of political stability in host countries. By detecting a curvilinear relationship between host country political stability and subsidiary survival in the primary sector, partially dependent upon the motives of the investing MNE (Brouthers et al., 2008), we help resolve a tension in the literature, namely that countries with highly stable political systems attract FDI (Bailey, 2018), while there are opportunities to exploit low stability (Barnard and Luiz, 2018; Petrou and Thanos, 2014). The answer, in the context of Japanese MNEs, during their most active period of international expansion, is that both perspectives are correct but that the potentially undesirable behavior is rare. This can be partially attributed to the higher scrutiny that home country regulators, such as the Securities Exchange Surveillance Commission in Japan, as well as international NGOs, are applying to reduce behaviors that take advantage of weak institutions. However, this may not be the case with MNEs from countries such as Brazil, China and India, where navigating informal governance practices is common. MNEs from these countries may show both greater ability and willingness to engage in non-market strategies, including those with dubious ethical implications, in less stable political environments (Barassi and Zhou, 2012).

\section{Limitations, Future Research and Conclusions}

Since the dataset is constrained to Japanese firms, the generalizability is limited beyond this sample. Governance of Japanese MNEs may be less risk-averse due to interlocking directorates (Buckley and Strange, 2011). According to the logic of our study, this suggests that many Japanese MNEs would be less averse to investing in countries with high political instability. Future studies may attempt to determine the extent to which country of origin impacts the 
relationships we found between political instability and subsidiary survival, depending on investment motives. Also, the various types of policy changes related to environmental stewardship, financial reporting, and other relevant policies, and their impact on the decision to invest, is another research avenue for future study. In particular, the impact of the COVID-19 pandemic on policy changes and foreign investment is an important area for future research. Furthermore, the examination of specific policies, rather than broad indices like political stability, can provide a more nuanced understanding of what types of policies produce the most vigorous response from MNE investors ${ }^{1}$.

Finally, we chose natural resource investments as the context for our study because the potential costs of compliance with increasingly stringent environmental requirements, dealing with corruption without resorting to bribery, and workplace health, safety, and benefits are large. However, this is also the case for a large variety of manufacturing subsidiaries, especially those in 'dirty industries' (Copeland and Taylor, 1994) and so replication and extension in other industries is warranted.

This study sought to investigate the extent to which natural resource subsidiary survival is impacted by location in a politically unstable country where, while transaction costs are typically higher, opportunities for exploiting less stringent legal requirements might entice MNEs to invest. We found that political risk has a curvilinear relationship with subsidiary survival, such that both high and low stability are associated with higher survival (lower exit hazard), while moderate levels of risk reduce subsidiary survival. This nonlinear relationship is stronger with the efficiencyseeking motive, and weaker with the market-seeking motive, as expected.

\footnotetext{
${ }^{1}$ We thank an anonymous reviewer for raising this important line of inquiry.
} 
The practical implication of our finding is that subsidiary survival is improved in host countries with high political risk, but the effect is very small in comparison with the effect of investment in countries with the highest political stability. Hence, while there may be benefits to the strategy of exploiting weak institutional environments, the benefits from doing so are diminishingly small, at least for Japanese MNEs. This effect should not be ignored, but controlling for the behavior through policy intervention will be difficult, and most certainly costly. The argument against globalization, that being that it creates a race to the institutional bottom, is probably exaggerated given the evidence shown in this study. Nonetheless, future research should keep contributing to the debate through empirical evidence, as the strength and influence of antiglobalization sentiment continue to mount, while the quantity of outward FDI is accelerating from countries outside the triad region of Japan, North America, and Western Europe. 


\section{References}

Akpomi, M.E. and Nnadi, M.A. (2017), "The impact of international financial reporting standards (IFRS) adoption on foreign direct investments (FDI): evidence from Africa and implications for managers of education", Journal of Accounting and Financial Management, Vol. 3 No. 2, pp. 51-65.

Alvaredo, F., Atkinson, A.B., Piketty, T. and Saez, E. (2013), "The top 1 percent in international and historical perspective", Journal of Economic Perspectives, Vol. 27 No. 3, pp. 3-20. doi: $10.1257 /$ jep.27.3.3

Ariño, A. (2003), "Measures of strategic alliance performance: An analysis of construct validity", Journal of International Business Studies, Vol. 34 No. 1, pp. 66-79. doi: 10.1057/palgrave.jibs.8400005

Austin, P.C. (2017), "A tutorial on multilevel survival analysis: methods, models and applications", International Statistical Review, Vol. 85 No. 2, pp. 185-203. doi: 10.1111/insr.12214

Bailey, N. (2018), "Exploring the relationship between institutional factors and FDI attractiveness: A metaanalytic review", International Business Review, Vol. 27 No. 1, pp. 139-148. doi: 10.1016/j.ibusrev.2017.05.012

Barassi, M.R. and Zhou, Y. (2012), "The effect of corruption on FDI: A parametric and non-parametric analysis", European Journal of Political Economy, Vol. 28 No. 3, pp. 302-312. doi: 10.1016/j.ejpoleco.2012.01.001

Barnard, H. (2008), "Uneven domestic knowledge bases and the success of foreign firms in the USA", Research Policy, Vol. 37 No. 10, pp. 1674-1683. doi: 10.1016/j.respol.2008.08.011

Barnard, H. and Luiz, J.M. (2018), "Escape FDI and the dynamics of a cumulative process of institutional misalignment and contestation: stress, strain and failure", Journal of World Business, Vol. 53 No. 5, pp. 605-619. doi: 10.1016/j.jwb.2018.03.010

Barry, C.M. (2016), "Bringing the company back in: a firm-level analysis of foreign direct investment", International Interactions, Vol. 42 No. 2, pp. 244-270. doi: 10.1080/03050629.2015.1065698

Benito, G.R. (2015), "Why and how motives (still) matter", Multinational Business Review, Vol. 23 No. 1, pp. 15-24. doi: 10.1108/MBR-02-2015-0005

Bertrand, O., Betschinger, M.-A. and Laamanen, T. (2019), "Effects of subnational regional corruption on growth strategies in emerging economies: evidence from Russian domestic and international M\&A activity", Global Strategy Journal, Vol. 9 No. 2, pp. 303-332. doi: 10.1002/gsj.1204

Bhagwati, J. (2002), "Coping with antiglobalization: a trilogy of discontents", Foreign Affairs, Vol. 81 No. 1, pp. 2-7. doi: $10.2307 / 20032998$

Bhagwati, J. (2004), "Anti-globalization: why?", Journal of Policy Modeling, Vol. 26 No. 4, pp. 439-463.

Brouthers, L.E., Gao, Y. and Mcnicol, J.P. (2008), "Corruption and market attractiveness influences on different types of FDI", Strategic management journal, Vol. 29 No. 6, pp. 673-680.

Buckley, P.J. (2018), "Internalisation theory and outward direct investment by emerging market multinationals", Management International Review, Vol. 58 No. 2, pp. 195-224. doi: $10.1007 / \mathrm{s} 11575-017-0320-4$

Buckley, P.J. and Strange, R. (2011), "The governance of the multinational enterprise: insights from internalization theory", Journal of Management Studies, Vol. 48 No. 2, pp. 460-470. doi: 10.1111/j.1467-6486.2010.00920.x

Cantwell, J., Dunning, J.H. and Lundan, S.M. (2010), "An evolutionary approach to understanding international business activity: the co-evolution of mnes and the institutional environment", Journal of International Business Studies, Vol. 41 No. 4, pp. 567-586. doi: 10.1057/jibs.2009.95

Casarin, A., Lazzarini, S.G. and Vassolo, R.S. (2020), "The forgotten competitive arena: strategy in natural resource industries", Academy of Management Perspectives, Vol. 34 No. 3, pp. 378-399. doi: 10.5465/amp.2017.0158

Cheng, S.M. (2006), "The role of labour cost in the location choices of Japanese investors in China", Papers in Regional Science, Vol. 85 No. 1, pp. 121-138. doi: 10.1111/j.1435-5957.2006.00066.x 
Chrysostome, E.V. and Lupton, N.C. (2011), "Characteristics and performance of Japanese foreign direct investment in Africa", International Journal of Economic Policy in Emerging Economies, Vol. 4 No. 1, pp. 54-77. doi: 10.1504/IJEPEE.2011.038873

Cleves, M., Gould, W. and Marchenko, Y. (2010). An Introduction to Survival Analysis Using Stata (Revisde Third Edition ed.), Stata press.

Coase, R.H. (1937), "The nature of the firm", Economica-New Series, Vol. 4 No. 16, pp. 386-405. doi: DOI 10.1111/j.1468-0335.1937.tb00002.x

Cooke, W.N. (1997), "The influence of industrial relations factors on us foreign direct investment abroad", Industrial \& Labor Relations Review, Vol. 51 No. 1, pp. 3-17. doi: 10.2307/2525031

Copeland, B.R. and Taylor, M.S. (1994), "North-south trade and the environment", The Quarterly Journal of Economics, Vol. 109 No. 3, pp. 755-787.

Crowley, F.D. and Loviscek, A.L. (2002), "Assessing the impact of political unrest on currency returns: a look at Latin America", The Quarterly Review of Economics and Finance, Vol. 42 No. 1, pp. 143153. doi: 10.1016/S1062-9769(01)00112-0

Crowther, M.J., Look, M.P. and Riley, R.D. (2014), "Multilevel mixed effects parametric survival models using adaptive Gauss-Hermite quadrature with application to recurrent events and individual participant data meta-analysis", Statistics in Medicine, Vol. 33 No. 22, pp. 3844-3858. doi: $10.1002 / \operatorname{sim} .6191$

Cuervo-Cazurra, A. (2016), "Corruption in international business", Journal of World Business, Vol. 51 No. 1, pp. 35-49. doi: 10.1016/j.jwb.2015.08.015

Cuervo-Cazurra, A., Gaur, A. and Singh, D. (2019), "Pro-market institutions and global strategy: the pendulum of pro-market reforms and reversals", Journal of International Business Studies, Vol. 50 No. 4, pp. 598-632. doi: 10.1057/s41267-019-00221-z

Darendeli, I., Hill, T.L., Rajwani, T. and Cheng, Y. (2020), "Surviving the Arab spring: socially beneficial product portfolios and resilience to political shock", Multinational Business Review, Vol. aheadof-print No. ahead-of-print. doi: 10.1108/MBR-11-2019-0156

Darendeli, I.S. and Hill, T.L. (2016), "Uncovering the complex relationships between political risk and MNE firm legitimacy: insights from Libya", Journal of International Business Studies, Vol. 47 No. 1, pp. 68-92. doi: 10.1057/jibs.2015.27

Dasgupta, S., Wheeler, D., Mody, A. and Roy, S. (1999). Environmental regulation and development: a cross-country empirical analysis, The World Bank.

Davies, R.B. and Vadlamannati, K.C. (2013), "A race to the bottom in labor standards? An empirical investigation", Journal of Development Economics, Vol. 103 No., pp. 1-14. doi: 10.1016/j.jdeveco.2013.01.003

Delios, A. and Beamish, P.W. (2001), "Survival and profitability: the roles of experience and intangible assets in foreign subsidiary performance", The Academy of Management Journal, Vol. 44 No. 5, pp. 1028-1038. doi: 10.2307/3069446

Delios, A. and Henisz, W.J. (2003), "Political hazards, experience, and sequential entry strategies: the international expansion of Japanese firms, 1980-1998", Strategic Management Journal, Vol. 24 No. 11, pp. 1153-1164. doi: 10.1002/smj.355

Demirbag, M., Apaydin, M. and Tatoglu, E. (2011), "Survival of Japanese subsidiaries in the Middle East and North Africa", Journal of World Business, Vol. 46 No. 4, pp. 411-425. doi: 10.1016/j.jwb.2010.10.002

Dunning, J.H. (1977), "Trade, location of economic activity and the multinational enterprise: a search for an eclectic approach", in B. Ohlin, P. O. Hesselborn, and P. M. Wikman (Ed.s), The International Allocation of Economic Activity, Macmillan, London, UK. pp. 395-418.

Dunning, J.H. (2000), "The eclectic paradigm as an envelope for economic and business theories of MNE activity", International Business Review, Vol. 9 No. 2, pp. 163-190. doi: 10.1016/S09695931(99)00035-9 
Dunning, J.H. and Lundan, S.M. (2008), "Institutions and the OLI paradigm of the multinational enterprise", Asia Pacific Journal of Management, Vol. 25 No. 4, pp. 573-593. doi: 10.1007/s10490007-9074-z

Friedman, T.L. (2000). The Lexus and the Olive Tree, Farrar, Strauss and Giroux, New York, NY.

García-Canal, E. and Guillén, M.F. (2008), "Risk and the strategy of foreign location choice in regulated industries", Strategic Management Journal, Vol. 29 No. 10, pp. 1097-1115. doi: 10.1002/smj.692

Gordon, L.A., Loeb, M.P. and Zhu, W. (2012), "The impact of IFRS adoption on foreign direct investment", Journal of Accounting and Public Policy, Vol. 31 No. 4, pp. 374-398. doi: 10.1016/j.jaccpubpol.2012.06.001

Guillén, M.F. (2001), "Is globalization civilizing, destructive or feeble? A critique of five key debates in the social science literature", Annual Review of Sociology, Vol. 27 No. 1, pp. 235-260. doi: 10.1146/annurev.soc.27.1.235

Hall, D. (1999), "Privatisation, multinationals, and corruption", Development in Practice, Vol. 9 No. 5, pp. 539-556. doi: 10.1080/09614529952657

Helmy, H.E. (2013), "The impact of corruption on FDI: Is MENA an exception?", International Review of Applied Economics, Vol. 27 No. 4, pp. 491-514. doi: 10.1080/02692171.2012.752445

Henisz, W.J. (2000), "The institutional environment for multinational investment", Journal of Law Economics \& Organization, Vol. 16 No. 2, pp. 334-364. doi: 10.1093/jleo/16.2.334

Hennart, J.F. and Park, Y.R. (1994), "Location, governance, and strategic determinants of Japanese manufacturing investment in the United States", Strategic Management Journal, Vol. 15 No. 6, pp. 419-436. doi: DOI 10.1002/smj.4250150602

Holburn, G.L.F. and Zelner, B.A. (2010), "Political capabilities, policy risk, and international investment strategy: evidence from the global electric power generation industry", Strategic Management Journal, Vol. 31 No. 12, pp. 1290-1315. doi: 10.1002/smj.860

Jackson, G. and Deeg, R. (2008), "Comparing capitalisms: understanding institutional diversity and its implications for international business", Journal of International Business Studies, Vol. 39 No. 4, pp. 540-561. doi: 10.1057/palgrave.jibs. 8400375

Jensen, N.M. (2006). Nation-States and the Multinational Corporation: A Political Economy of Fforeign Direct Investment, Princeton University Press, Princeton, NJ.

Jiménez, A. and Alon, I. (2018), "Corruption, political discretion and entrepreneurship", Multinational Business Review, Vol. 26 No. 2, pp. 111-125. doi: 10.1108/MBR-01-2018-0009

Jones, G. (2005). Multinationals and Global Capitalism: from the Nineteenth to the Twenty-First Century, Oxford University Press on Demand.

Keefer, P. and Knack, S. (2002), "Polarization, politics and property rights: links between inequality and growth", Public Choice, Vol. 111 No. 1-2, pp. 127-154. doi: 10.1023/A:1015168000336

Kobrin, S.J. (1979), "Political risk - review and reconsideration", Journal of International Business Studies, Vol. 10 No. 1, pp. 67-80. doi: 10.1057/palgrave.jibs.8490631

Kolstad, I. and Wiig, A. (2013), "Digging in the dirt? Extractive industry FDI and corruption", Economics of Governance, Vol. 14 No. 4, pp. 369-383. doi: 10.1007/s10101-013-0133-2

Lawton, T. and Rajwani, T. (2011), "Designing lobbying capabilities: Managerial choices in unpredictable environments", European Business Review, Vol. 23 No. 2, pp. 167-189. doi: $10.1108 / 09555341111111192$

Lawton, T., Rajwani, T. and Doh, J. (2013), "The antecedents of political capabilities: a study of ownership, cross-border activity and organization at legacy airlines in a deregulatory context", International Business Review, Vol. 22 No. 1, pp. 228-242. doi: 10.1016/j.ibusrev.2012.04.001

Lewin, A.Y. and Peeters, C. (2006), "Offshoring work: Business hype or the onset of fundamental transformation?", Long Range Planning, Vol. 39 No. 3, pp. 221-239. doi: 10.1016/j.lrp.2006.07.009

Li, J., Li, Y. and Shapiro, D. (2012), "Knowledge seeking and outward FDI of emerging market firms: the moderating effect of inward FDI", Global Strategy Journal, Vol. 2 No. 4, pp. 277-295. doi: 10.1111/j.2042-5805.2012.01042.x 
Li, X. and Zhou, Y.M. (2017), "Offshoring pollution while offshoring production?", Strategic Management Journal, Vol. 38 No. 11, pp. 2310-2329. doi: 10.1002/smj.2656

Makino, S., Lau, C.M. and Yeh, R.S. (2002), "Asset-exploitation versus asset-seeking: implications for location choice of foreign direct investment from newly industrialized economies", Journal of International Business Studies, Vol. 33 No. 3, pp. 403-421. doi: 10.1057/palgrave.jibs.8491024

Márquez-Ramos, L. (2011), "European accounting harmonization: consequences of IFRS adoption on trade in goods and foreign direct investments", Emerging Markets Finance and Trade, Vol. 47 No. sup4, pp. 42-57. doi: 10.2753/REE1540-496X4705S403

Mayer, T., Mejean, I. and Nefussi, B. (2010), "The location of domestic and foreign production affiliates by French multinational firms", Journal of Urban Economics, Vol. 68 No. 2, pp. 115-128. doi: 10.1016/j.jue.2010.03.006

Mccarthy, N. (2019), "Oil and gas giants spend millions lobbying to block climate change policies", available at: https://www.forbes.com/sites/niallmccarthy/2019/03/25/oil-and-gas-giants-spendmillions-lobbying-to-block-climate-change-policies-infographic/?sh=26a135bf7c4f, (accessed 25 November 2020).

Mckinney, J.A. and Moore, C.W. (2008), "International bribery: does a written code of ethics make a difference in perceptions of business professionals", Journal of Business Ethics, Vol. 79 No. 1, pp. 103-111. doi: 10.1007/s10551-007-9395-3

Mcmullen, J.S. and Bergman, B.J. (2018), "The promise and problems of price subsidization in social entrepreneurship", Business Horizons, Vol. 61 No. 4, pp. 609-621. doi: 10.1016/j.bushor.2018.03.009

Meschi, P.X., Phan, T.T. and Wassmer, U. (2016), "Transactional and institutional alignment of entry modes in transition economies: a survival analysis of joint ventures and wholly owned subsidiaries in Vietnam", International Business Review, Vol. 25 No. 4, pp. 946-959. doi: 10.1016/j.ibusrev.2015.12.005

Meyer, K. (2015), "What is 'strategic asset seeking FDI'?", Multinational Business Review, Vol. 23 No. 1, pp. 57-66. doi: 10.1108/MBR-02-2015-0007

Meyer, K.E. (2017), "International business in an era of anti-globalization", Multinational Business Review, Vol. 25 No. 2, pp. 78-90. doi: 10.1108/MBR-03-2017-0017

Nnadi, M. and Soobaroyen, T. (2015), "International financial reporting standards and foreign direct investment: the case of Africa", Advances in Accounting, Vol. 31 No. 2, pp. 228-238. doi: 10.1016/j.adiac.2015.09.007

North, D.C. (1987), "Institutions, transaction costs and economic-growth", Economic Inquiry, Vol. 25 No. 3, pp. 419-428. doi: 10.1111/j.1465-7295.1987.tb00750.x

Park, H. (2003), "Determinants of corruption: a cross-national analysis", Multinational Business Review, Vol. 11 No. 2, pp. 29-48. doi: 10.1108/1525383X200300010

Petrou, A.P. and Thanos, I.C. (2014), "The 'grabbing hand' or the 'helping hand' view of corruption: evidence from bank foreign market entries", Journal of World Business, Vol. 49 No. 3, pp. 444454. doi: 10.1016/j.jwb.2013.10.004

Piketty, T. (2014), "Capital in the twenty-first century: a multidimensional approach to the history of capital and social classes", British Journal of Sociology, Vol. 65 No. 4, pp. 736-747. doi: 10.1111/14684446.12115

Pinkse, J. and Kolk, A. (2012), "Multinational enterprises and climate change: Exploring institutional failures and embeddedness", Journal of International Business Studies, Vol. 43 No. 3, pp. 332-341. doi: $10.1057 /$ jibs.2011.56

Rodriguez, P., Uhlenbruck, K. and Eden, L. (2005), "Government corruption and the entry strategies of multinationals", Academy of Management Review, Vol. 30 No. 2, pp. 383-396. doi: 10.5465/amr.2005.16387894

Rosenbusch, N., Gusenbauer, M., Hatak, I., Fink, M. and Meyer, K.E. (2019), "Innovation offshoring, institutional context and innovation performance: a meta-analysis", Journal of Management Studies, Vol. 56 No. 1, pp. 203-233. doi: 10.1111/joms.12407 

10.1111/issr. 12091

Schott, P.K. (2003), "One size fits all? Heckscher-Ohlin specialization in global production", American Economic Review, Vol. 93 No. 3, pp. 686-708-708. doi: 10.1257/000282803322157043

Schultz, H. (2009). "Political institutions and foreign direct investment in developing countries: does the sector matter?", working paper, Available at SSRN: https://ssrn.com/abstract=1403983,

Slangen, A.H.L. and Van Tulder, R.J.M. (2009), "Cultural distance, political risk, or governance quality? Towards a more accurate conceptualization and measurement of external uncertainty in foreign entry mode research", International Business Review, Vol. 18 No. 3, pp. 276-291. doi: 10.1016/j.ibusrev.2009.02.014

Surroca, J., Tribó, J.A. and Zahra, S.A. (2013), "Stakeholder pressure on MNEs and the transfer of socially irresponsible practices to subsidiaries", Academy of Management Journal, Vol. 56 No. 2, pp. 549572. doi: $10.5465 / \mathrm{amj} .2010 .0962$

Tang, J. (2015), "Testing the pollution haven effect: does the type of FDI matter?", Environmental and Resource Economics, Vol. 60 No. 4, pp. 549-578. doi: 10.1007/s10640-014-9779-7

Uhlenbruck, K., Rodriguez, P., Doh, J. and Eden, L. (2006), "The impact of corruption on entry strategy: evidence from telecommunication projects in emerging economies", Organization Science, Vol. 17 No. 3, pp. 402-414. doi: 10.1287/orsc.1060.0186

Vetter, H. (2017), "Commodity taxes and welfare under endogenous market conduct", Journal of Economics, Vol. 122 No. 2, pp. 137-154. doi: 10.1007/s00712-017-0538-4

Wagner, U.J. and Timmins, C.D. (2009), "Agglomeration effects in foreign direct investment and the pollution haven hypothesis", Environmental and Resource Economics, Vol. 43 No. 2, pp. 231-256. doi: $10.1007 / \mathrm{s} 10640-008-9236-6$

Weingast, B.R. (1993), "Constitutions as governance structures: The political foundations of secure markets", Journal of Institutional and Theoretical Economics (JITE) / Zeitschrift für die gesamte Staatswissenschaft, Vol. 149 No. 1, pp. 286-311.

Weng, D.H. and Peng, M.W. (2018), "Home bitter home: how labor protection influences firm offshoring", Journal of World Business, Vol. 53 No. 5, pp. 632-640. doi: 10.1016/j.jwb.2018.03.007

White, G.O., Hemphill, T.A., Joplin, J.R.W. and Marsh, L.A. (2014), "Wholly owned foreign subsidiary relation-based strategies in volatile environments", International Business Review, Vol. 23 No. 1, pp. 303-312. doi: 10.1016/j.ibusrev.2013.05.006

Witt, M.A. and Lewin, A.Y. (2007), "Outward foreign direct investment as escape response to home country institutional constraints", Journal of International Business Studies, Vol. 38 No. 4, pp. 579594. doi: 10.1057/palgrave.jibs.8400285

Yasuda, N. and Mitsuhashi, H. (2017), "Learning from political change and the development of MNCs' political capabilities: Evidence from the global mining industry", Management International Review, Vol. 57 No. 5, pp. 749-774. doi: 10.1007/s11575-017-0318-y

Yi, J., Meng, S., Macaulay, C.D. and Peng, M.W. (2019), "Corruption and foreign direct investment phases: the moderating role of institutions", Journal of International Business Policy, Vol. 2 No. 2, pp. 167-181. doi: 10.1057/s42214-019-00024-x

Yim, H.R., Lu, J. and Choi, S.J. (2017), "Different role of lobbying and bribery on the firm performance in emerging markets", Multinational Business Review, Vol. 25 No. 3, pp. 222-238. doi: 10.1108/MBR-07-2017-0050 
Figure1. Kaplan-Meier Failure Estimations

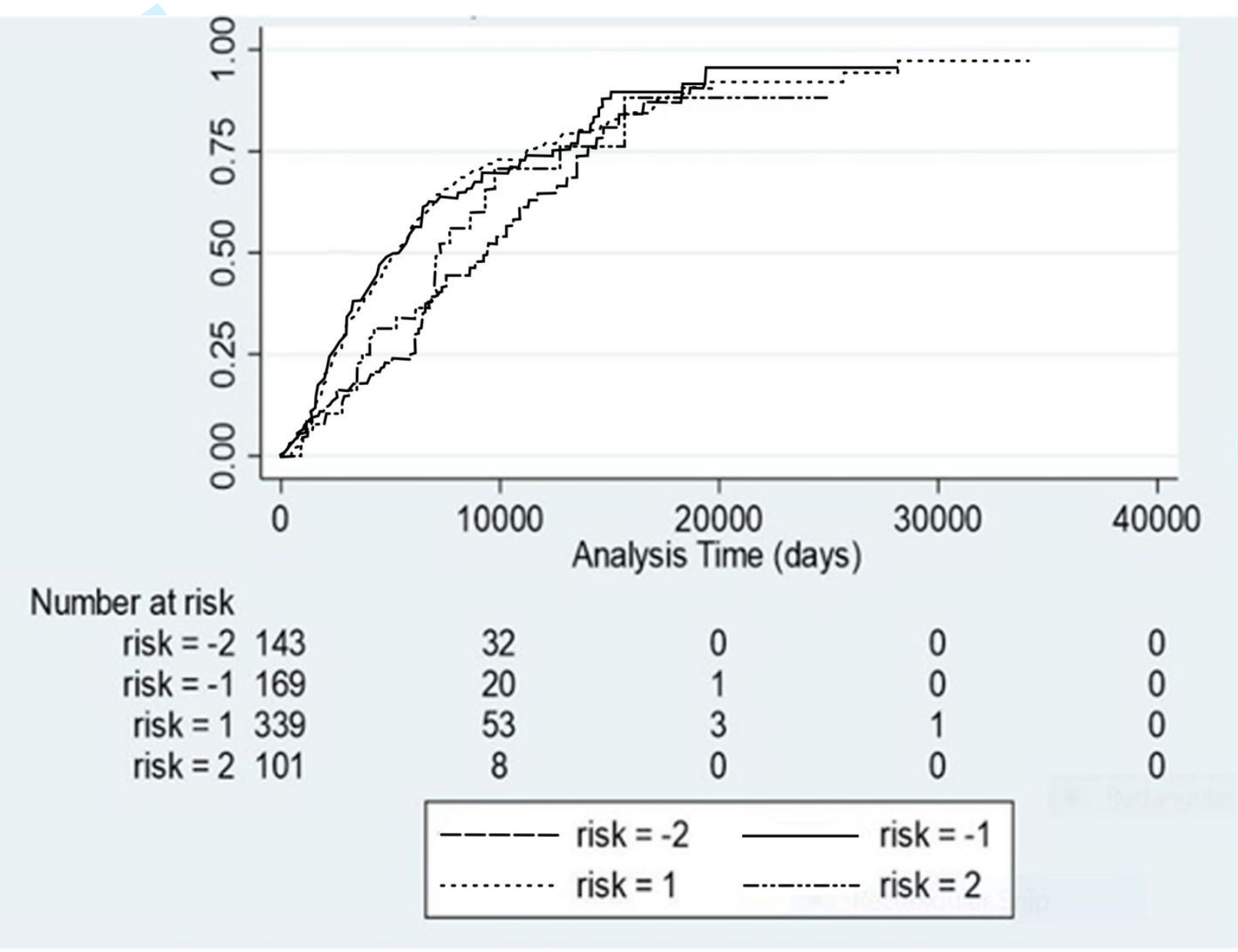

*risk $-2,-1,2,1$ represent the standard deviation of the political risk 
Table 1.

Categories of investment purpose

\begin{tabular}{|c|c|c|c|c|}
\hline Seeking Category & Investment Purpose* & $\begin{array}{l}\text { Compliance } \\
\text { Area }\end{array}$ & Associated Costs & $\begin{array}{l}\text { Impact on Investment } \\
\text { Motives }\end{array}$ \\
\hline \multirow{3}{*}{$\begin{array}{l}\text { Natural resources } \\
\text { seeking } \\
\text { Market seeking }\end{array}$} & Resources and materials & \multirow{3}{*}{$\begin{array}{l}\text { Natural } \\
\text { environmental } \\
\text { standards }\end{array}$} & \multirow{3}{*}{$\begin{array}{l}\text { Associated Costs } \\
\text { Emissions Monitoring } \\
\text { Impact Monitoring } \\
\text { Clean up costs }\end{array}$} & $\begin{array}{l}\text { Natural Resource } \\
\text { Seeking - very high }\end{array}$ \\
\hline & $\begin{array}{l}\text { Constriction of international } \\
\text { distribution network }\end{array}$ & & & $\begin{array}{l}\text { Efficiency Seeking } \\
\text { (labor)- Low }\end{array}$ \\
\hline & Local market expansions & & & Market-Seeking - High \\
\hline \multirow[t]{5}{*}{ Efficiency seeking } & Labor seeking & & & $\begin{array}{l}\text { Asset Seeking - mixed } \\
\text { effect }\end{array}$ \\
\hline & Reverse import to Japan & $\begin{array}{l}\text { Labor market } \\
\text { standards }\end{array}$ & $\begin{array}{l}\text { Hiring costs } \\
\text { Benefits costs }\end{array}$ & $\begin{array}{l}\text { Natural resource } \\
\text { seeking - High }\end{array}$ \\
\hline & $\begin{array}{l}\text { Follow customers, suppliers, } \\
\text { and related firms }\end{array}$ & & $\begin{array}{l}\text { Physical safety } \\
\text { procedures }\end{array}$ & $\begin{array}{l}\text { Efficiency Seeking } \\
\text { (Labor) - Very High }\end{array}$ \\
\hline & Export to third countries & & Hiring costs & Market seeking Low \\
\hline & $\begin{array}{l}\text { Construction of international } \\
\text { production network }\end{array}$ & & & Asset Seeking Low \\
\hline \multirow[t]{3}{*}{ Strategic asset seeking } & $\begin{array}{l}\text { Collection of information, } \\
\text { knowledge seeking, royalty }\end{array}$ & \multirow{3}{*}{$\begin{array}{l}\text { International } \\
\text { Financial } \\
\text { Reporting } \\
\text { Standards }\end{array}$} & \multirow{3}{*}{$\begin{array}{l}\text { Transparency of } \\
\text { market data } \\
\text { Quality of financial } \\
\text { information }\end{array}$} & $\begin{array}{l}\text { Natural Resource } \\
\text { Seeking - Low }\end{array}$ \\
\hline & $\begin{array}{l}\text { Research, development product } \\
\text { planning }\end{array}$ & & & $\begin{array}{l}\text { Efficiency Seeking } \\
\text { (labor)- Low }\end{array}$ \\
\hline & Expansions into new business & & & $\begin{array}{l}\text { Market-Seeking - High } \\
\text { Efficiency Seeking } \\
\text { (labor)- Low }\end{array}$ \\
\hline
\end{tabular}

*Source: Toyo Keizai Overseas Investment (TK) dataset, 2014. 
Table 2.

Correlations, means, standard deviations, and ranges of observations

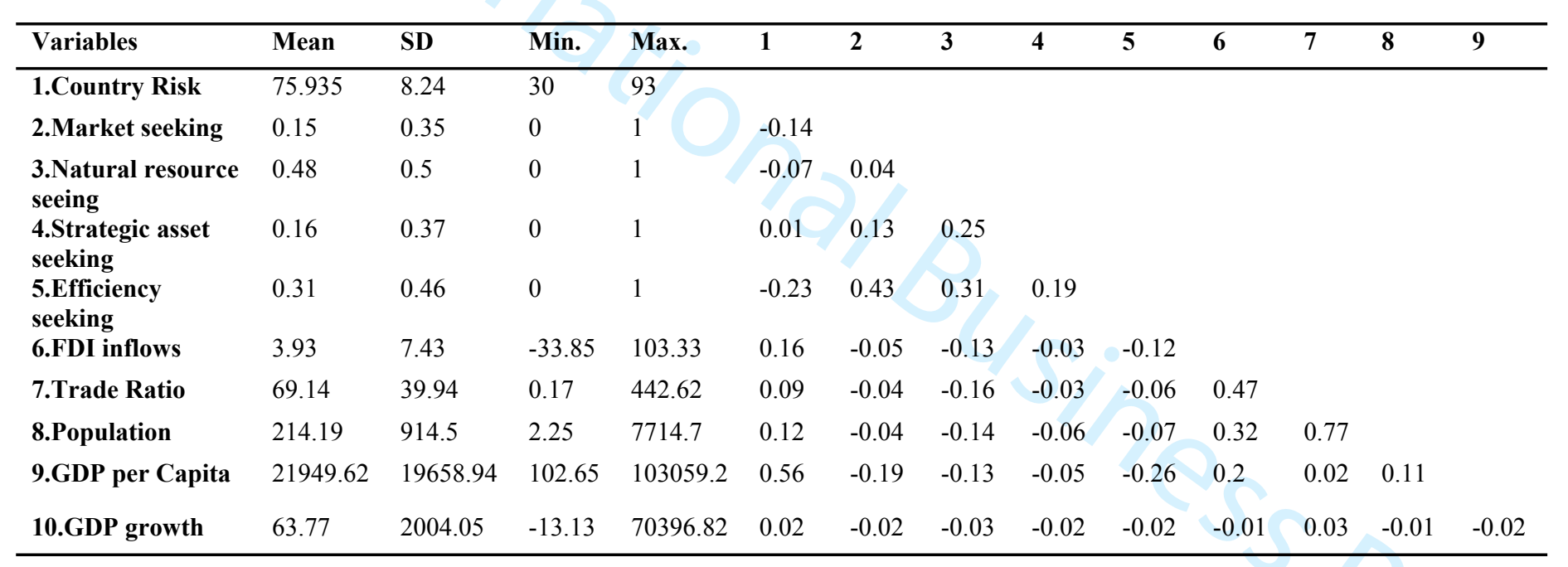


Table 3.

Mixed effect parametric (Weibull) survival model results

\begin{tabular}{|c|c|c|c|c|c|c|c|}
\hline Variables & Model 1 & Model 2 & Model 3 & Model 4 & Model 5 & Model 6 & Model 7 \\
\hline FDI inflow & $0.025^{*}$ & $0.023^{* *}$ & $0.021^{* *}$ & $\begin{array}{l}0.018^{*} \\
0.088\end{array}$ & $\begin{array}{l}0.02 * \\
(0.08)\end{array}$ & $0.021^{* *}$ & $\begin{array}{l}0.02 \\
0.008\end{array}$ \\
\hline Trade ratio & $\begin{array}{l}-0.001 \\
(0.002)\end{array}$ & $\begin{array}{l}-0.002 \\
(-0.002)\end{array}$ & $\begin{array}{l}-0.001 \\
(-0.002)\end{array}$ & $\begin{array}{l}-0.001 \\
(0.002)\end{array}$ & $\begin{array}{l}-0.001 \\
(0.002)\end{array}$ & $\begin{array}{l}-0.001 \\
0.002\end{array}$ & $\begin{array}{l}-0.001 \\
0.002\end{array}$ \\
\hline $\begin{array}{l}\text { Population } \\
\text { GDP per capita }\end{array}$ & $\begin{array}{l}0.001^{*} \\
(0.001) \\
0.00\end{array}$ & $\begin{array}{l}0.001^{\dagger} \\
(-0.001) \\
0.00\end{array}$ & $\begin{array}{l}0.001 * \\
(-0.001) \\
0.00\end{array}$ & $\begin{array}{l}0.001^{*} \\
(0.001) \\
0.00\end{array}$ & $\begin{array}{l}0.001 * \\
(0.001) \\
0.00\end{array}$ & $\begin{array}{l}0.001 \\
0.001 \\
0.00\end{array}$ & $\begin{array}{l}0.001 * \\
0.001 \\
0.00\end{array}$ \\
\hline $\begin{array}{l}\text { GDP growth } \\
\text { Country risk }\end{array}$ & $\begin{array}{l}(0.00) \\
-0.001 \\
(0.001)\end{array}$ & $\begin{array}{l}(0.00) \\
-0.001 \\
(0.001) \\
0.045^{* *}\end{array}$ & $\begin{array}{l}(0.00) \\
-0.001 \\
(0.001) \\
0.527^{* *}\end{array}$ & $\begin{array}{l}(0.00) \\
-0.001 \\
(0.001) \\
0.589^{* *}\end{array}$ & $\begin{array}{l}(0.00) \\
-0.001 \\
(0.001) \\
0.432 * *\end{array}$ & $\begin{array}{l}0.00 \\
-0.001 \\
0.001 \\
0.612^{* *}\end{array}$ & $\begin{array}{l}0.00 \\
-0.001 \\
0.001 \\
0.525^{* *}\end{array}$ \\
\hline Country risk ${ }^{2}$ & & $(0.012)$ & $\begin{array}{l}(0.112) \\
-0.004 * *\end{array}$ & $\begin{array}{l}(0.152) \\
-0.005^{* *}\end{array}$ & $\begin{array}{l}(0.116) \\
-0.003 * *\end{array}$ & $\begin{array}{l}0.123 \\
-0.005^{* *}\end{array}$ & $\begin{array}{l}0.116 \\
-0.004 * *\end{array}$ \\
\hline Resource seeking & & & $(-0.001)$ & $\begin{array}{l}(0.002) \\
5.175\end{array}$ & $(0.001)$ & 0.001 & 0.001 \\
\hline Resource seeking $\times$ Country Risk & & & & $\begin{array}{l}(7.611) \\
-0.215\end{array}$ & & & \\
\hline Resource seeking $\times$ Country Risk ${ }^{2}$ & & & & $\begin{array}{l}(0.216) \\
0.002\end{array}$ & & & \\
\hline Efficiency seeking & & & & $(0.002)$ & $\begin{array}{l}-25.033 \\
(12.43)\end{array}$ & & \\
\hline Efficiency seeking $\times$ Country Risk & & & & & $\begin{array}{l}0.672^{*} \\
(0.345)\end{array}$ & & \\
\hline Efficiency seeking $\times$ Country Risk ${ }^{2}$ & & & & & $\begin{array}{l}-0.005^{*} \\
(0.003)\end{array}$ & & \\
\hline Market seeking & & & & & & $\begin{array}{l}20.649 \\
(10.69)\end{array}$ & \\
\hline Market seeking $\times$ Country Risk & & & & & & $\begin{array}{l}-0.555^{+} \\
(0.309)\end{array}$ & \\
\hline Market seeking $\times$ Country Risk ${ }^{2}$ & & & & & & $\begin{array}{l}0.004 \\
(0.003)\end{array}$ & \\
\hline Strategic asset seeking & & & & & & & $\begin{array}{l}-6.391 \\
(15.432)\end{array}$ \\
\hline $\begin{array}{l}\text { Strategic asset seeking } \times \text { Country } \\
\text { Risk }\end{array}$ & & & & & & & 0.149 \\
\hline $\begin{array}{l}\text { Strategic asset seeking } \times \text { Country } \\
\text { Risk }^{2}\end{array}$ & & & & & & & $\begin{array}{l}(0.428) \\
-0.001\end{array}$ \\
\hline $\begin{array}{l}\text { Constant } \\
\text { Number of observations }\end{array}$ & $\begin{array}{l}-30.196^{* *} \\
(4.001) \\
5.610\end{array}$ & $\begin{array}{l}-31.447^{* *} \\
(3.223) \\
5.603\end{array}$ & $\begin{array}{l}-45.933^{* *} \\
(5.152) \\
5.603\end{array}$ & $\begin{array}{l}-47.725^{* *} \\
(6.405) \\
5.603\end{array}$ & $\begin{array}{l}-41.136^{* *} \\
(5.086) \\
5.603\end{array}$ & $\begin{array}{l}-49.239 \\
(5.622) \\
5.603\end{array}$ & $\begin{array}{l}-4.003) \\
-45.772 \\
(5.26) \\
5.603\end{array}$ \\
\hline $\begin{array}{l}\text { Log likelihood (LL) } \\
\text { Wald chi2 }\end{array}$ & $\begin{array}{l}-4678.183 \\
16.12\end{array}$ & $\begin{array}{l}-4661.174 \\
31.07\end{array}$ & $\begin{array}{l}-4652.204 \\
39.84\end{array}$ & $\begin{array}{l}-4642.531 \\
62.75\end{array}$ & $\begin{array}{l}-4648.891 \\
42.86\end{array}$ & $\begin{array}{l}-4648.486 \\
46.34\end{array}$ & $\begin{array}{l}-4649.124 \\
47.71\end{array}$ \\
\hline Prob $>$ chi $^{2}$ & 0.0065 & 0.00 & 0.00 & 0.00 & 0.00 & 0.00 & 0.00 \\
\hline
\end{tabular}


Significance levels: *** $\mathrm{p}<0.001, * * \mathrm{p}<0.01, * \mathrm{p}<0.05, \mathrm{f} \mathrm{p}<0.10$. Standard deviation of coefficients is in parentheses.

NOTE: Country Risk is an index, and so it is mean centered and standardized prior to entry into the regression to improve interpretability of the coefficients. Other variables are not standardized, as the coefficients can be interpreted in terms of the original units. 